SUSTAINABLE FORESTRY

COLLECTION 81-82, 2020
ODRŽIVO ŠUMARSTVO

ZBORNIK RADOVA 81-82, 2020

UDK $630 * 165.5: 630 * 232.31=111$

Original scientific paper

\title{
VARIABILITY OF MORPHOMETRIC CHARACTERISTICS OF HUNGARIAN OAK (Quercus frainetto Ten.) ACORN
}

\author{
Vladan POPOVIĆ , Aleksandar LUČIĆ ${ }^{l}$, Ljubinko RAKONJAC ${ }^{l}$, \\ Sanja JOVANOVIĆ ${ }^{\text {, Ivica LAZAREVIĆ }}$
}

\begin{abstract}
The results of morphometric analysis of Hungarian oak seeds originating from Lipovica Forest Management Unit are presented in this paper. The seeds have been collected from 50 trees evenly distributed on the forest management unit area. The length, width and mass of acorns are measured on the sample consisting of 50 acorns per tree. The volume and shape index of acorns are calculated based on the measured values of their length and width. The mean values of morphometric characteristics obtained in research indicate there is a high variability among the studied genotypes. The latter has also been confirmed by means of an analysis of variance which determined statistically significant differences between the sampled mother trees for all the observed morphometric characteristics. The results obtained represent a good starting point for future research on breeding of the species and can be utilised for improvement of the mass production of high quality Hungarian oak planting material in Serbia.
\end{abstract}

Key words: Hungarian oak, acorn, population, genetic variability.

\section{VARIJABILNOST MORFOMETRIJSKIH SVOJSTAVA ŽIRA SLADUNA (Quercus frainetto Ten.)}

Izvod: U radu su prikazani rezultati morfometrijske analize semena hrasta sladuna poreklom iz GJ „Lipovica“. Seme je sakupljeno sa 50 stabala ravnomerno raspoređenih po površini gazdinske jedinice, a na uzorku od 50 žireva po stablu izmereni su dužina, širina $i$ masa žira. Na osnovu izmerenih vrednosti dužine i širine izračunati su zapremina $i$ indeks oblika žira. Prosečne vrednosti morfometrijskih svojstava, dobijene u istraživanjima, ukazuju na visoku varijabilnost između proučavanih genotipova. To je potvđeno i analizom varijanse,

\footnotetext{
${ }^{1}$ Institute of Forestry, Belgrade, Serbia

${ }^{2}$ PE “Šume-Goč” Vrnjačka Banja, Serbia
} 
gde su utvrđene statistički značajne razlike između uzorkovanih materinskih stabala za sva posmatrana morfometrijska svojstva. Dobijeni rezultati predstavljaju dobru polaznu osnovu za buduća istraživanja u oplemenjivanju vrste i mogu poslužiti za unapređenje masovne proizvodnje kvalitetnog repromaterijala sladuna u Srbiji.

Ključne reči: sladun, žir, populacija, genetička varijabilnost.

\section{INTRODUCTION}

The Hungarian oak (Quercus frainetto Ten.) is an oak species growing in thermophilous broadleaved forests in Southeastern Europe. The largest part of prevalence is on the Balkan Peninsula, but it also occurs in the Northwest of Turkey and the South of Italy. It grows in a wide vegetation belt rich in woody species. It mainly grows in habitats with subcontinental climate conditions, frequent summer droughts, highest amount of precipitation during spring, wide temperature range and low winter temperatures (Horvat et al., 1974). The Hungarian oak as one of the edifiers, is most often present in Serbia together with Turkey oak in climatogenic community of Hungarian oak and Turkey oak Quercetum frainetto-cerridis Rudski 1949. Except typical climatic-zonal forest Quercetum farnetto-cerris Rud.1949 a number of sub-associations representing different ecological variants of Hungarian oak and Turkey oak forests are described in Serbia (Stajić et al., 2008). Except the sub-associations, several geographic variants have also been singled out within the Hungarian oak and Turkey oak forest understood in a broad sense. (Tomić and Rakonjac, 2013). It is in contact with inhabited areas and agricultural land. Therefore, it is under constant pressure which leads to gradual reduction of area of these forests. The areas covered by Hungarian oak forests reduced significantly in the last century due to anthropogenic influence. This has had a very negative effect on genetic diversity of Hungarian oak. The natural regeneration of Hungarian oak is very difficult. It is mainly regenerated vegetatively which additionally contributes to the reduction of genetic diversity.

Forests are classified in the most complex ecosystems on the Earth due to the high level of diversity in terms of genetic resources, abundance of species and habitat diversity (Geburek and Konrad, 2008). Due to constant pressure exerted on forests in the last few centuries and disappearance of natural forests, biodiversity is endangered (Carabeo et al., 2016). The long-term survival of species is closely related to their genetic diversity (Gapare, 2014). Under the influence of changed environmental conditions, biotic pathogens and damages survival and evolution of species depend on the level of genetic diversity (Reed and Frankham, 2003). The research dealing with genetic diversity and identifying populations with high genetic variability can help in reducing loss of biological diversity (Souto et al., 2015).

An increasing number of researchers in Serbia and abroad is engaged in research of quality and quantity of yield of forest trees. The degree of exploration of genetic variability of quantity and quality of seed yield of various forest tree species and possibility of their use in our conditions is still below the actual needs and it is not in line with the economic significance this field could provide (Popović et al., 2015). The results of the studies of Tucović, (1975), Tucović and Stilinović, (1982), 
Šijačić-Nikolić et al., (2007, 2010), Lučić et al., (2011), Popović et al., (2012, 2015), Nonić, M. et al. (2012) and other authors have contributed to gradual completion of knowledge related to intrapopulation and interpopulation variability of various species of forest trees on the level of seed and juvenile stage of development.

The objective of the research in this paper is to determine intrapopulation variability of Hungarian oak according to the morphological characteristics of acorns. The results obtained in the research can be used as preliminary introduction on genetic variability of the studied population, proposal of measures for preservation of the available gene pool and improvement of production of high quality seed and planting material.

\section{MATERIAL AND METHODS}

The acorns from the yield of 2019 originating from Lipovica Forest Management Unit, Belgrade Forest Estate, Belgrade were used for research in this paper. On the basis of phenotypic characteristics and abundance of yield 50 mother trees were singled out. The mother trees are evenly distributed on the area of the forest management unit and minimum distance between them is $50 \mathrm{~m}$ in order to avoid relatedness. About $3 \mathrm{~kg}$ of ocularly healthy and undamaged acorns was collected per tree regardless of their dimensions. After the collection acorns were dried up to $35 \%$ humidity and stored at the temperature of $3-5^{\circ} \mathrm{C}$.

The analyses of measured and derived morphometric characteristics were carried out on a random sample consisting of 50 acorns per mother tree. Length, width in the widest part and mass of acorns were measured. The length and width of acorns were measured by vernier caliper with the accuracy of $0.01 \mathrm{~mm}$ and mass by electronic scale with the accuracy of $0.01 \mathrm{~g}$. Shape index, volume of acorns and average number of acorns in $1 \mathrm{~kg}$ were calculated based on the measured values. The shape index of an acorn was calculated as the ratio of the length and width of the acorn. The volume of an acorn was calculated according to the formula for the volume of cylinder (the shape of an acorn was approximated by cylinder). The average number of acorns in $1 \mathrm{~kg}$ was calculated based on the average mass of one acorn, separately for each of the sampled mother trees. (Ivanković et al., 2011).

Morphological characteristics of acorns were described by descriptive statistical indicators: arithmetic mean (x), standard deviation (SD) and coefficient of variation (CV \%). One-way analysis of variance (ANOVA) was used to determine intrapopulation variability. A mother tree was the analysed variability factor. All the above statistical analyses were carried out using the statistical program STATISTICA 7.0 (StatSoft Inc., 2004). 


\section{RESULTS AND DISCUSSION}

The mean value of acorn length at the level of population amounted to 24.84 $\mathrm{mm}$ and ranged from $20.13 \mathrm{~mm}$ (Tree 9) to $30.19 \mathrm{~mm}$ (Tree 44), with standard deviation from $1.08 \mathrm{~mm}$ to $4.06 \mathrm{~mm}$ (Table 1).

The mean value of acorn width in the widest part amounted to $11.79 \mathrm{~mm}$, with the range from $10.6 \mathrm{~mm}$ (Tree 11) to $14.55 \mathrm{~mm}$ (Tree 42) and standard deviation from $0.64 \mathrm{~mm}$ to $1.47 \mathrm{~mm}$ (Table 1 ).

The highest mean value of acorn mass amounted to $3.71 \mathrm{~g}$ (Tree 20) and the lowest was $1.18 \mathrm{~g}$ (Tree 9), while mean value at the level of stand amounted to 2.13 $\mathrm{g}$ with standard deviation from $0.3 \mathrm{~g}$ to $1.04 \mathrm{~g}$ (Table 1).

The acorn shape index ranged from 1.65 (Tree 25) to 2.45 (Tree 48), with mean value at the level of stand amounting to 1.98 and standard deviation from 0.1 to 0.39 (Table 1).

The mean value of acorn volume at the level of stand amounted to $3.18 \mathrm{~cm}^{3}$. The acorn volume ranged from $2.03 \mathrm{~cm}^{3}$ (Tree 11) to $4.81 \mathrm{~cm}^{3}$ (Tree 20) with standard deviation from $0.35 \mathrm{~cm}^{3}$ to $1.22 \mathrm{~cm}^{3}$ (Table 1).

When comparing the mean values of morphological characteristics of acorns determined in this paper with the data cited in literature, it is evident that they are quite similar, which is expected given that a similar methodology was used.

Table 1. Descriptive statistics of the measured acorn characteristics

\begin{tabular}{|c|c|c|c|c|c|c|c|c|c|c|c|c|c|c|c|}
\hline \multirow{2}{*}{ Tree } & \multicolumn{3}{|c|}{ Length (mm) } & \multicolumn{3}{|c|}{ Width (mm) } & \multicolumn{3}{|c|}{ Mass (g) } & \multicolumn{3}{|c|}{ Shape index } & \multicolumn{3}{|c|}{ Volume $\left(\mathrm{mm}^{3}\right)$} \\
\hline & $\mathbf{M}$ & SD & CV & M & SD & CV & $\mathbf{M}$ & SD & CV & $\mathbf{M}$ & SD & $\mathrm{CV}$ & $\mathbf{M}$ & SD & CV \\
\hline 1 & 24.47 & 2.19 & 8.96 & 12.39 & 0.96 & 7.73 & 2.56 & 0.56 & 21.88 & 1.98 & 0.11 & 5.74 & 3.00 & 0.66 & 21.95 \\
\hline 2 & 24.62 & 2.83 & 11.51 & .01 & & 6.94 & 2.63 & 0.72 & 27.53 & 89 & & 10.01 & 31 & & 21.87 \\
\hline 3 & 2.09 & 1.83 & 8.30 & .01 & 69 & 5.78 & .20 & 0.46 & & 1.84 & & & & & 15.43 \\
\hline 4 & 2.16 & 1.52 & 6.85 & 1.60 & 0.83 & 7.18 & 1.46 & 0.43 & 29.67 & 1.92 & & & 2.36 & 41 & 17.40 \\
\hline 5 & 23.79 & 2.95 & 12.40 & 11.08 & 1.41 & 12.75 & 1.31 & 0.52 & 39.88 & 2.18 & 0.39 & 17.90 & 2.33 & .70 & 29.85 \\
\hline 6 & 22.29 & 1.66 & 7.43 & 11.36 & 1.04 & 9.19 & 1.30 & 0.54 & 41.74 & 1.97 & 0.21 & 10.44 & 2.28 & 0.49 & 21.49 \\
\hline 7 & 21.89 & 1.96 & 8.96 & 11.42 & 0.70 & 6.1 & 1.31 & 0.49 & 37.48 & 1.92 & 18 & 9.40 & 2.26 & 0.39 & 17.39 \\
\hline 8 & 26.04 & 1.93 & 7.40 & 13.63 & 0 & 5.9 & 2.69 & 0.6 & 23.92 & 1.91 & & & 3.83 & & 16.85 \\
\hline 9 & 20.13 & 2.15 & 10.70 & .36 & 0 & 8.4 & 1.18 & 0.3 & 25.87 & 1.78 & & 0.94 & 2.07 & 0.49 & 23.63 \\
\hline 10 & 20.76 & 1.90 & 9.13 & 1.33 & 0.69 & 6.1 & 1.41 & 0.42 & 29.85 & 1.84 & & & 2.11 & 37 & 17.43 \\
\hline 11 & 22.93 & 1.62 & 7.09 & 10.60 & 0.80 & 7.5 & 1.33 & 0.40 & 29.80 & 2.18 & 0.23 & 10.57 & 2.03 & 0.35 & 17.35 \\
\hline 12 & .26 & 1.87 & 7.71 & 1.98 & 0.94 & 7.89 & 1.72 & 0.39 & 22.53 & 2.03 & 0.16 & & 2.76 & 0.61 & 22.11 \\
\hline 13 & 26.30 & 1.57 & 5.98 & 12.90 & 0.77 & 5.9 & 2.44 & 0.44 & 18.18 & 2.04 & 11 & & & 56 & 16.17 \\
\hline 14 & 24.02 & 1.6 & 6.86 & .67 & & 6. & 2.12 & 0. & 23.21 & 1.90 & & & 3.0 & & 19.27 \\
\hline 15 & 24.48 & 1.62 & 6.63 & 12.47 & 0.92 & 7.4 & 2.14 & 0.52 & 24.53 & 1.97 & & & 3.02 & & 20.73 \\
\hline 16 & 25.13 & 2.4 & 9.64 & 1.83 & 1.09 & 9.2 & 1.88 & 0.5 & 26.57 & 2.13 & & & 2.81 & & 26.41 \\
\hline 17 & 24.94 & 1.4 & 5.95 & 13.38 & 1.11 & 8.2 & 2.68 & 0.62 & 23.20 & 1.87 & 0.12 & & 3.55 & 0.74 & 20.88 \\
\hline 18 & 25.50 & 1.56 & 6.11 & 12.87 & 1.08 & 8.4 & 2.47 & 0.61 & 24.71 & 1.99 & 0.14 & & 3.36 & 0.71 & 21.16 \\
\hline 19 & 24.19 & 1.95 & 8.05 & 11.57 & 0.82 & 7.1 & 1.90 & 0.45 & 23.52 & 2.10 & 0.17 & 8.09 & 2.57 & 0.50 & 19.41 \\
\hline 20 & 29.29 & 1.53 & 5.24 & 14.41 & 1.03 & 7.1 & 3.71 & 0.58 & 15.69 & 2.04 & 0.13 & 6.58 & 4.81 & 0.84 & 17.37 \\
\hline 21 & 26.03 & 4.0 & 15.61 & 0 & 1.30 & 9.6 & 2.62 & 0.9 & 37.86 & 1.94 & 0.20 & 10. & 3.7 & & 32.26 \\
\hline & & 1.7 & 6.73 & 2 & 1.2 & 9. & 2.30 & 0.6 & 26.80 & 1.89 & & & 3.6 & & \\
\hline 23 & 27.32 & 2.0 & 7.51 & 12.44 & 0.84 & 6. & 2.24 & 0.5 & 22.31 & 2.20 & & & 3.34 & & 17.79 \\
\hline 2 & 24.73 & 2. & 8.61 & 11.97 & 1.20 & 10. & 1.81 & 0.42 & 23.20 & 2.08 & 0.26 & 12. & 2.82 & 0.64 & 22.69 \\
\hline 25 & 22.89 & 1.4 & 6.31 & 13.92 & 1.02 & 7.3 & 2.44 & 0.63 & 25.90 & 1.65 & 0.13 & 7.6 & 3.51 & 0.65 & 18.47 \\
\hline 26 & 22.79 & 1.41 & 6.18 & 12.97 & 0.64 & 4.92 & 2.22 & 0.48 & 21.46 & 1.76 & 0.11 & 6.24 & 3.02 & 0.40 & 13.41 \\
\hline 27 & 22.85 & 2.07 & 9.06 & 12.62 & 0.78 & 6.1 & 1.71 & 0.5 & 30.84 & 1.81 & 0.14 & 53 & 2.89 & 0.54 & 18.67 \\
\hline 28 & 25.49 & 2.2 & 8.97 & 12.05 & 0.86 & 7.1 & 1.96 & 0.6 & 33.45 & 2.12 & 0.18 & & 2.94 & 0.58 & 19.62 \\
\hline 29 & 32 & 1.87 & 7.69 & 12.53 & 1.08 & 8.6 & 1.80 & 0.49 & 27.45 & 1.95 & 0.19 & 9.78 & 3.03 & 0.67 & 22.18 \\
\hline 0 & & 1.81 & .1 & & .00 & 8.6 & 6.14 & & & .19 & 0.13 & 8.32 & 3.26 & 0.08 & \\
\hline
\end{tabular}




\begin{tabular}{|c|c|c|c|c|c|c|c|c|c|c|c|c|c|c|c|}
\hline \multirow{2}{*}{ Tree } & \multicolumn{3}{|c|}{ Length (mm) } & \multicolumn{3}{|c|}{ Width (mm) } & \multicolumn{3}{|c|}{ Mass (g) } & \multicolumn{3}{|c|}{ Shape index } & \multicolumn{3}{|c|}{ Volume $\left(\mathrm{mm}^{3}\right)$} \\
\hline & M & SD & CV & $\mathbf{M}$ & SD & CV & $\mathbf{M}$ & SD & CV & M & SD & CV & $\mathbf{M}$ & SD & CV \\
\hline 31 & 24.69 & 2.73 & 11.08 & 13.25 & 0.80 & 6.07 & 1.75 & 0.57 & 32.43 & 1.86 & 0.16 & 8.59 & 3.45 & 0.72 & 20.75 \\
\hline 32 & .72 & & 7.2 & & & & 53 & 72 & & 89 & & 16 & 79 & 76 & 19.91 \\
\hline 3. & 65 & & & .22 & & & 09 & & & 88 & & & .20 & 61 & 4.5 \\
\hline 3 & & & 2 & .04 & & & 63 & & & 1.88 & & & J & & 21. \\
\hline 35 & & 1.6 & 6.52 & .84 & & 5.7 & 52 & 91 & 35.87 & 1.80 & & 7.4 & 3.75 & .54 & 14. \\
\hline 36 & 73 & 1.34 & 5.64 & 11.31 & 0. & 6.1 & 1.85 & 0.30 & 16.08 & 2.10 & 0.14 & 6.89 & 2.40 & 0.36 & 15.15 \\
\hline 37 & 50 & 2.23 & 9.92 & 12.26 & & 8.36 & .87 & 0.43 & 23.04 & 1.84 & 0.19 & 10.26 & 2.69 & 50 & 22.21 \\
\hline 38 & & & & 2.52 & & & 2.23 & & 25. & 2.00 & & & 12 & & 22.45 \\
\hline 39 & & & & 13.1 & & & 63 & & 18.35 & 1.91 & & & 3.45 & & 19.71 \\
\hline 4 & & & 5.6 & 11.72 & & 7.2 & .75 & & 23.83 & 1.99 & & 8.1 & 2.53 & & 17.17 \\
\hline 4 & 50 & 2.1 & 8.6 & 13.63 & & 6.5 & 2.06 & .76 & 36.83 & 1.80 & 0.10 & 5.32 & 3.62 & 0.76 & 21.08 \\
\hline 42 & .12 & 1.68 & 6.20 & 14.55 & 1.20 & 8.2 & 3.15 & 0.71 & 22.65 & 1.87 & 0.14 & 7.27 & 4.56 & 0.92 & 20.05 \\
\hline 43 & .57 & 2.32 & 8.74 & 14.21 & 1.47 & 10.32 & 2.95 & 1.04 & 35.16 & 1.88 & 0.18 & 9.51 & 4.29 & 1.09 & 25.30 \\
\hline 4 & & 2.3 & 7.89 & 3.64 & & 7.0 & 3.39 & 72 & 21.14 & 2.22 & & 5.7 & 1.46 & 94 & 20.97 \\
\hline 4 & & 2.4 & & 1.21 & & 7.6 & 1.67 & & 29.21 & 2.42 & & 9. & 2.69 & & 19.36 \\
\hline 4 & & 2.0 & 8.2 & 14.20 & & 8.1 & 2.06 & 0.6 & 31.02 & 1.80 & & 11. & 4.05 & & 18.9 \\
\hline & & & 6.3 & 12.62 & & 6.5 & 1.87 & 0.5 & 29.63 & 2.13 & & & 3.3 & & 16.6 \\
\hline 4 & & 1.0 & & 11.90 & & 7.0 & 2.16 & 0.3 & 15.60 & 2.49 & & 6.8 & 3.30 & & 15.6 \\
\hline 4 & & 2.37 & & 13.15 & & 7.2 & 2.50 & 0.65 & 26.12 & 2.14 & & 7.4 & 3.85 & 0.80 & 20.87 \\
\hline 50 & 3.29 & 3.04 & 10. & 11.45 & 0.80 & 7.0 & 1.96 & 0.56 & 28.49 & 2.47 & 0.17 & 7.0 & 2.96 & 0.69 & 23.42 \\
\hline Mean & 24.84 & 2.93 & 11.79 & 12.62 & 1.38 & 10.91 & 2.13 & 0.81 & 38.19 & 1.98 & 0.24 & 12.32 & 3.18 & 0.93 & 29.3 \\
\hline
\end{tabular}

The most variable characteristic at the level of stand is acorn mass (38.19 $\%)$, while acorn width at the widest part is the characteristic showing the lowest variability $(10.91 \%)$ (Table 1$)$.

The average number of acorns in $1 \mathrm{~kg}$ at the level of stand amounts to 470 pieces and it ranges from 269 pieces per $\mathrm{kg}$ (Tree 20) to 849 pieces per $\mathrm{kg}$ (Tree 9).

Table 2. The analysis of variance for measured morphometric characteristics of acorn

\begin{tabular}{|c|l|l|l|l|l|l|l|c|}
\hline Parameter & $\begin{array}{c}\text { SS } \\
\text { Effect }\end{array}$ & $\begin{array}{c}\text { df } \\
\text { Effect }\end{array}$ & $\begin{array}{c}\text { MS } \\
\text { Effect }\end{array}$ & $\begin{array}{c}\text { SS } \\
\text { Error }\end{array}$ & $\begin{array}{c}\text { df } \\
\text { Error }\end{array}$ & $\begin{array}{c}\text { MS } \\
\text { Error }\end{array}$ & \multicolumn{1}{|c}{} & p \\
\hline Acorn length & 6899.9 & 49 & 140.8 & 5958.1 & 1450 & 4.1 & 34.3 & 0.0000 \\
\hline Acorn width & 1485.2 & 49 & 30.3 & 1356.3 & 1450 & 0.9 & 32.4 & 0.0000 \\
\hline Acorn mass & 486.525 & 49 & 9.929 & 501.475 & 1450 & 0.346 & 28.71 & 0.0000 \\
\hline Shape index & 46.689 & 49 & 0.953 & 42.6 & 1450 & 0.029 & 32.4 & 0.0000 \\
\hline Acorn volume & 676.36 & 49 & 13.8 & 629.6 & 1450 & 0.43 & 31.79 & 0.0000 \\
\hline
\end{tabular}

The results of the performed analysis of variance are presented in Table 2. The studied source of variability was a tree (family) within a population. The results obtained have shown that there are statistically significant differences caused by the studied source of variability for all studied morphometric characteristics of acorns which confirms the hypothesis about significant intrapopulation differentiation. A research on interpopulation and intrapopulation variability of Hungarian oak in east Croatia was conducted by Prokupić (2020). A study confirmed a satisfying level of variability, using leaf morphological characteristics.

Large statistically significant differences detected between individual parent trees (genotypes) within a population indicate there is a high level of intrapopulation genetic diversity. Statistically significant differences between the studied parent trees of pedunculate oak for the analysed morphometric characteristics of acorn clearly indicate genetic differentiation and high level of intrapopulation variability (Popović et al.. 2020). The high level of intrapopulation variability in a bald cypress 
stand is determined on the basis of morphometric characteristics of cones (Popovic et al., 2012). The occurrence of a high level of intrapopulation variability is characteristic of the majority of forest tree species and it can be explained by the gene flow process (exchange of genes between different populations through natural processes and also by human actions) and low level of local adaptedness (Bogdan, 2009).

\section{CONCLUSION}

The conducted research of morphometric characteristics of Hungarian oak acorn on the level of population contributes to better knowledge of the analysed characteristics and their effect on differentiation of the studied genotypes.

The following mean values are determined on the level of the studied genotypes: acorn length $24.84 \mathrm{~mm}$, acorn width $12.62 \mathrm{~mm}$, mass $2.13 \mathrm{~g}$, shape index 1.98 and volume $3.18 \mathrm{~cm}^{3}$. There are, on average, 470 pieces of acorn per kilogram.

Statistically significant differences between the studied parent trees for all the analysed morphometric characteristics of acorn clearly indicate genetic differentiation and high level of intrapopulation variability.

The results obtained can be used for preliminary assessment of genetic variability of the studied population, proposal of measures for conservation and sustainable use of the available gene pool and improvement of production of Hungarian oak plant material in Serbia.

Acknowledgements: This study was carried out under the Agreement on realisation and funding of scientific research activity of scientific research organisations in 2020 funded by the Ministry of Education, Science and Technological Development of the Republic of Serbia, No. 451-03-68/2020-14/200027 from January 24, 2020.

\section{REFERENCES}

Bogdan, S. (2009): Genetika s oplemenjivanjem drveća i grmlja (interna skripta). Šumarski fakultet Sveučilišta u Zagrebu, 1-207. [Bogdan, S. (2009): Genetics with tree and shrub breeding (internal script). Faculty of Forestry, University of Zagreb, 1-207.]

Carabeo, M, Simeone, M.C., Cherubini, M., Mattia, C., Chiocchini, F., Bertini, L., Caruso, C., La Mantia, T., Villani, F., Mattionia, C. (2016): Estimating the genetic diversity and structure of Quercus trojana Webb populations in Italy by SSRs: implications for management and conservation. Can J Forest Res. 47: 331-339.

Gapare, W.J. (2014): Merging applied gene conservation activities with advanced generation breeding initiatives: a case of study of Pinus radiate D. Don. New For. 45: 311-331.

Geburek, T., Konrad, H. (2008): Why the conservation of forest genetic resources has not worked. Conserv. Biol. 22(2): 267-274.

Horvat, L., Glavac, V., Ellemberg, H. (1974): Vegetation Suedosteuropas. Geobot. Selecta 4. G. Fischer, Stuttgart. 
Ivanković, M., Popović, M., Bogdan, S. (2011): Varijabilnost morfometrijskih svojstava žireva i visina sadnica hrasta lužnjaka (Quercus robur L.) iz sjemenskih sastojina u Hrvatskoj. Šumarski list-Posebni broj, (46-58). [Ivanković, M., Popović, M., Bogdan, S. (2011): Acorn morphometric traits and seedling heights variation of pedunculate oak (Quercus robur L.) from the seed stands in Croatia, Šumarski list-Posebni broj, (46-58).]

Lučić, A., Rakonjac, Lj., Isajev, V., Živadinović, V. (2011): Varijabilnost morfometrijskih svojstava šišarica belog bora (Pinus sylvestris L.) u Srbiji, Šumarstvo, 1-2, 83-94. [Lučić, A., Rakonjac, Lj., Isajev, V., Živadinović, V. (2011): Variability of morphometric characteristics of Scots pine (Pinus sylvestris L.) cones in Serbia. Šumarstvo, 1-2, 83-94.]

Nonić, M., Popović, V., Kerkez, I., Šijačić-Nikolić, M. (2013): Varijabilnost morfometrijskih karakteristika semena različitih test stabala divlje trešnje (Prunus avium L.) sa područja Beograda, Šumarstvo, 1-2, 113-123. [Nonić, M., Popović, V., Kerkez, I., Šijačić-Nikolić, M. (2013): Variability of morphometric characteristics of seeds of different wild cherry (Prunus avium L.) test trees in Belgrade area, Šumarstvo, 1-2, 113-123.]

Popović, V., Šijačić-Nikolić, M. (2015): Analiza kvaliteta i morfometrijskih karakteristika semena bukve (Fagus moesiaca/Domin, Maly/Czeczott) u Srbiji, Šumarstvo, 1-2, 109-120. [Popović, V., Šijačić-Nikolić, M. (2015): The analysis of quality and morphometric characteristics of beech (Fagus moesiaca/Domin, Maly/Czeczott) seeds in Serbia, Šumarstvo, 1-2, 109-120.]

Popović, V., Šijačić-Nikolić, M., Rakonjac, Lj., Jokanović, D. (2012): Variability in cone morphometric characters among test trees of bald cypress (Taxodium distichum L. Rich.) in seed stand near Bačka Palanka. Sustainable Forestry, 65-66, 15-27.

Popović, V., Lučić, A., Rakonjac, Lj., Kerkez Janković, I. (2020): Varijabilnost morfometrijskih svojstava žira i jednogodišnjih sadnica hrasta lužnjaka (Quercus robur L.) na nivou semenske sastojine RS-2-2-qro-11-828, Šumarstvo, 1-2, 1-11. [Popović, V., Lučić, A., Rakonjac, Lj., Kerkez Janković, I. (2020): Variability of morphometric characteristics of pedunculate oak (Quercus robur L.) acorn and one-year old seedlings at the level of seed stand RS-2-2-qro-11-828, Šumarstvo, 1-2, 1-11.]

Prokupić, M. (2020): Varijabilnost hrasta sladuna (Quercus frainetto Ten.) na području istočne Hrvatske prema morfološkim obilježjima listova (diplomski rad). Šumarski fakultet Sveučilišta u Zagrebu.

Reed, D.H., Frankham, R. (2003): Correlation between fitness and genetic diversity. Conserv. Biol. 17: 230-237.

Souto, C., Mathiasen, P., Acosta, M. (2015): Identifying genetic hotspots by mapping molecular diversity of widespread trees: when commonness matters. J. Hered. 106: 537-545.

Stajić, S., Rakonjac, Lj., Čokeša, V. (2008): Phytocoenological characteristics of Hungarian oak and Turkey oak with hornbeam forest (Carpino betuli-Quercetum farnetto-cerris) in the area of Bogovadja. Sustainable Forestry, 57-58, 104-114.

Šijačić-Nikolić, M., Milovanović, J., Knežević, R. (2010): Variability of cone morphological traits and seed quality parameters of Norway spruce sample genotypes from Kopaonik 
mountain - First Serbia Forestry Congress - Future with Forests, 11-13 November, 2010, Faculty of Forestry Belgrade, Serbia, Congress Abstracts, 157.

Šijačić-Nikolić, M., Ivetić, V., Knežević, R., Milovanović, J. (2007): Analiza svojstava semena i klijavaca različitih provenijencija brdske bukve. Acta biologica iugoslavica - serija G: Acta herbologica, 16(1), 15-27. [Šijačić-Nikolić, M., Ivetić, V., Knežević, R., Milovanović, J. (2007): Analysis of seed and seedling traits of different provenances of beech. Acta biologica iugoslavica - serija G: Acta herbologica, 16(1), 15-27.]

Tomić, Z., Rakonjac, Lj. (2013): Šumske fitocenoze Srbije, Institut za šumarstvo Beograd, Univerzitet Singidunum-Fakultet za primenjenu ekologiju Futura, Beograd. [Tomić, Z., Rakonjac, Lj. (2013): Forest phytocoenoses of Serbia, Institute of Forestry Belgrade, Faculty of Applied Ecology Futura of Singidunum University, Belgrade.]

Tucović, A. (1975): Praktikum iz genetike sa oplemenjivanjem biljaka. Izdavačko preduzeće Građevinska knjiga. Beograd, 1-233. [Tucović, A. (1975): Genetics with Plant Breeding Practicum. Publishing Company Građevinska knjiga. Belgrade, 1-233.]

Tucović, A., Stilinović, S. (1982): Stanje i problemi u proizvodnji genetski kvalitetnog semena u SR Srbiji iz semenskih plantaža. Glasnik Šumarskog fakulteta, 58, 3-21. [Tucović, A., Stilinović, S. (1982): Status and problems in the production of genetically high quality seed in the Socialist Republic of Serbia from seed orchards. Bulletin of the Faculty of Forestry, 58, 3-21.]

\title{
VARIABILITY OF MORPHOMETRIC CHARACTERISTICS OF HUNGARIAN OAK (Quercus frainetto Ten.) ACORN
}

\author{
Vladan POPOVIĆ, Aleksandar LUČIĆ, Ljubinko RAKONJAC, \\ Sanja JOVANOVIĆ, Ivica LAZAREVIĆ
}

\section{Summary}

The Hungarian oak (Quercus frainetto Ten.) is an oak species growing in thermophilous broadleaved forests in Southeastern Europe. The areas covered by Hungarian oak forests are reduced significantly due to anthropogenic influence exerted in the last century. This had very negative effect to genetic diversity of Hungarian oak. The natural regeneration of Hungarian oak is very difficult. It is mainly regenerated vegetatively which additionally contributes to the reduction of genetic diversity.

The objective of the research in this paper is to determine intrapopulation variability of Hungarian oak according to the morphological characteristics of acorns.

The results of morphometric analysis of Hungarian oak seeds originating from Lipovica Forest Management Unit are presented in this paper. The seeds have been collected from 50 trees selected based on phenotypical characteristics and abundance of yield, evenly distributed on the forest management unit area. The analyses of measured and derived morphometric characteristics were carried out on a random sample consisting of 50 acorns per mother tree. Length, width in the widest part and mass of acorns were measured. Shape index, volume of acorns and average number of acorns in $1 \mathrm{~kg}$ were calculated based on the measured values. 
Mean values determined on the level of the studied genotypes are as follows: acorn length $24.84 \mathrm{~mm}$, acorn width $12.62 \mathrm{~mm}$, mass $2.13 \mathrm{~g}$, shape index 1.98 and volume 3.18 $\mathrm{cm}^{3}$. There are, on average, 470 pieces of acorn per kilogram.

The results of the performed analysis of variance have shown that there are statistically significant differences caused by the studied source of variability (genotype) for all studied morphometric characteristics of acorns. Large statistically significant differences detected between individual parent trees (genotypes) within a population indicate there is a high level of intrapopulation genetic diversity.

The results obtained can be used for preliminary assessment of genetic variability of the studied population, proposal of measures for conservation and sustainable use of the available gene pool and improvement of production of Hungarian oak plant material in Serbia.

\title{
VARIJABILNOST MORFOMETRIJSKIH SVOJSTAVA ŽIRA SLADUNA (Quercus frainetto Ten.)
}

\author{
Vladan POPOVIĆ, Aleksandar LUČIĆ, Ljubinko RAKONJAC, \\ Sanja JOVANOVIĆ, Ivica LAZAREVIĆ
}

\section{Rezime}

Sladun (Quercus frainetto Ten.) je vrsta hrasta koja raste u termofilnim listopadnim šumama u jugoistočnoj Evropi. Zbog antropogenog uticaja u prošlom veku, površine po sladunovim šumama su značajno redukovane, a to je veoma negativno uticalo na njegov genetički diverzitet. Prirodno obnavljanje sladuna je veoma otežano, uglavnom se obnavlja vegetativnim putem, što dodtno utiče na smanjenje genetičkog diverziteta.

Cilj istraživanja u ovom radu je da se utvrdi unutarpopulaciona varijabilnost sladuna prema morfološkim svojstvima žireva.

U radu su prikazani rezultati morfometrijske analize semena hrasta sladuna poreklom iz GJ „Lipovica“. Seme je sakupljeno sa 50 stabala selektovanih na osnovu fenotipskih karakteristika i obilnosti uroda, ravnomerno raspoređenih po površini gazdinske jedinice. Analize merenih i izvedenih morfometrijskih svojstava vršene su na slučajnom uzorku koji je činilo 50 žireva po svakom materinskom stablu. Mereni su dužina, širina na najširem delu i masa žireva. Na osnovu izmerenih vrednosti izračunata su sledeća svojstva: indeks oblika, zapremina žireva i prosečan broj žireva u jednom kilogramu.

$\mathrm{Na}$ nivou proučavanih genotipova utvrđene su sledeće prosečne vrednosti: dužina žira 24,84 mm, širina žira $12,62 \mathrm{~mm}$, masa $2,13 \mathrm{~g}$, indeks oblika 1,98 i zapremina $3,18 \mathrm{~cm}^{3}$. U jednom kilogramu prosečno ima 470 komada žireva.

Rezultati provedene analize varijanse su pokazali postojanje statistički značajnih razlika uzrokovanih posmatranim izvorom varijabilnosti (genotip) za sva istraživana morfometrijska svojstva žira. Visoke statistički značajne razlike utvrđene između individualnih roditeljskih stabala (genotipova) unutar populacije ukazuju na visok nivo unutarpopulacone genetske raznolikosti.

Dobijeni rezultati mogu poslužiti za preliminarnu procenu genetičkog varijabiliteta istraživane populacije, predlog mera za očuvanje i održivo korišćenje raspoloživog genofonda i unapređenje proizvodnje repromaterijala hrasta sladuna u Srbiji. 